\title{
A New Method for the Preparation of Oxazaborolidine Catalyst In Situ Using 1,2-Aminoalcohol, Sodium Borohydride, and Diiodomethane for the Asymmetric Reduction of Prochiral Ketones and $\boldsymbol{N}$-Substituted Imines
}

\author{
Hichem Sadrik Kettouche* and Abdel Hafid Djerourou
}

\author{
Laboratory of Synthesis and Organic Biocatalysis, Faculty of Sciences, University of Badji Mokhtar, BP 12, 23000, \\ Annaba, Algeria
}

\begin{abstract}
An oxazaborolidine catalyst is readily prepared in situ at room temperature in THF using 1,2-aminoalcohols and borane generated from sodium borohydride $/ \mathrm{CH}_{2} \mathrm{I}_{2}$ reagent system. The oxazaborolidine $/ \mathrm{BH}_{3}$ reagent system prepared in this way is useful for the reduction of prochiral ketones and $N$-substituted imines to the corresponding alcohols and amines with moderate to good enantiomeric excesses.
\end{abstract}

Keywords: Asymmetric reduction, oxazaborolidine, borane, ketone, imine.

\section{INTRODUCTION}

Chiral organoborane reagents, in particular 1,3,2- oxazaborolidines, have been extensively studied and applied as efficient Lewis acid catalysts to a wide range of asymmetric transformations $[1,2]$. B-H oxazaborolidines are commonly used as convenient catalyst for the enantioselective borane carbonyl functionalities. However, it has been widely employed in the reduction with $\mathrm{ZrCl}_{4}[3 \mathrm{C}, 6], \mathrm{Me}_{3} \mathrm{SiCl}[7,8]$, $\mathrm{BF}_{3} \mathrm{O}_{2} \mathrm{OEt}_{2}$ [8], $\mathrm{ZnCl}_{2}$ [9], $\mathrm{I}_{2}$ [4,10,17], Lanthanoid [11], $\left(\mathrm{PhCO}_{2} \mathrm{H}, \mathrm{H}_{3} \mathrm{BO}_{3}\right)$ [12], $\mathrm{SnCl}_{4}$ [13a], $\mathrm{CoCl}_{3}$ [13b], $\mathrm{H}_{2} \mathrm{SO}_{4}$ [14], etc, in THF solution instead of $\mathrm{BH}_{3}$ reagents. Also chiral 1,2-aminoalcohol, such as valinol and leucinol [3c,6],

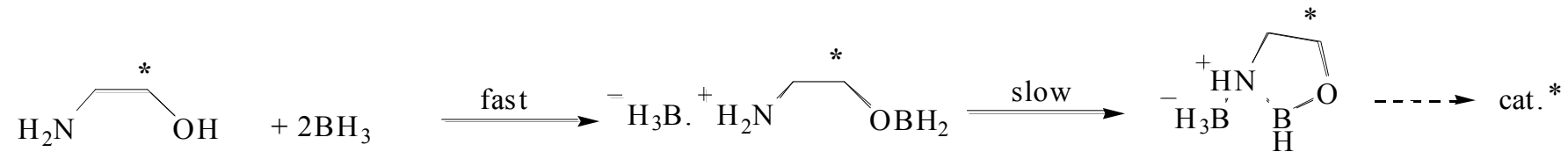

Scheme 1. Mechanism of the catalyst formation.

reduction of prochiral ketones, imines, and oximes [1a,c-f,3]. The most used method described in the literature for the preparation of B-H oxazaborolidines is by the in situ reaction of chiral aminoalcohols with an excess of borane without isolation and characterization of the catalyst [1-3]. We have reported from this laboratory that borane -THF prepared in situ using $\mathrm{NaBH}_{4}$ and $\mathrm{I}_{2}$ in THF is useful for several synthetic applications that require borane-THF (Table 1). Unfortunately, the $\alpha, \alpha$-diphenylpyrrolidinemethanol and $\mathrm{NaBH}_{4} / \mathrm{I}_{2}$ combination gave poor results in the asymmetric reduction of acetophenone [4]. Herein we report that the $\mathrm{NaBH}_{4}, \mathrm{CH}_{2} \mathrm{I}_{2}$ and 1,2-aminoalcohols combination is useful for the asymmetric reduction of ketones and imines to obtain the corresponding alcohols and amines with moderate to good enantiomeric excess.

\section{RESULTS AND DISCUSSION}

The $\mathrm{NaBH}_{4}$ species has been reported to have good reactivity as a reducing agent [5]. This reagent has been used for the reduction of a wide large number of representative

*Address correspondence to this author at the Laboratory of Synthesis and Organic Biocatalysis, Faculty of Sciences, University of Badji Mokhtar, BP 12,23000, Annaba, Algeria; E-mail: sadrik9@yahoo.fr
2-( $\alpha$-hydroxybenzyl)benzimidazole [15], $\alpha, \alpha$-diphenylpyrroldinemethanol [4,7b], 12,sulfonamide [8], azacrownethers [16], ferrocenylaminoalcohol [17] has been used in the asymmetric reduction with $\mathrm{NaBH}_{4}$.

It has been reported that $\mathrm{NaBH}_{4}$ could not reduce diiodomethane to methyl iodide [18]. We have observed that the sodium borohydride $\left(\mathrm{NaBH}_{4}\right) / \mathrm{CH}_{2} \mathrm{I}_{2}$ reagent system in the presence of 1,2- aminoalcohol affords a very easy and simple preparation of the oxazaborolidines catalyst (Fig. 1, Scheme 1), as well as the $\mathrm{BH}_{3}$ species, which effectively reduces acetophenone within about $30 \mathrm{~min}$ at $25{ }^{\circ} \mathrm{C}$ and Phenyl $(1-$ phenylethylidene)amine (6) within about $2 \mathrm{~h}$ at $25^{\circ} \mathrm{C}$ (Scheme 2, Table 1).

Initially, we examined the reduction of acetophenone (5) using the sodium borohydride $\left(\mathrm{NaBH}_{4}\right) / \mathrm{CH}_{2} \mathrm{I}_{2}$ combination under the influence of $(R)$-leucinol (1) $(10 \mathrm{~mol} \%)$ in THF at $25{ }^{\circ} \mathrm{C}$. In this case, the desired alcohol (7) was obtained in $84 \%$ yield and $72 \%$ ee. Stereoselectivities up to $87 \%$ ee in the presence of $(R)$-valinol (2) were reached with acetophenone (5). We observed that the $\mathrm{NaBH}_{4} / \mathrm{CH}_{2} \mathrm{I}_{2}$ reagent system in the presence of catalyst $(R)$-prolinol (4) (10 mol\%) yielded the desired alcohol 7 in $88 \%$ yield and $49 \%$ ee. The poor results were obtained with $(R)$-methioninol (3) $(23 \%$ 
<smiles>CC(C)C[C@H](N)CO</smiles>

$(R)-1$

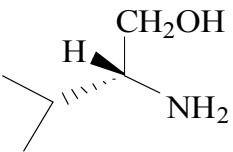

$(\boldsymbol{R})-2$<smiles>CSCC[C@H](N)CO</smiles>

$(\boldsymbol{R})-3$<smiles>OC[C@@H]1CCCN1</smiles>

$(R)-4$

Fig. (1). Chiral aminoalcohols used to the preparation of chiral oxazaborolidine.<smiles>CC(=O)c1ccccc1</smiles>

5<smiles>CC(=Nc1ccccc1)c1ccccc1</smiles>

(R)-1,2-aminoalcohol(100mol\%) $+\mathrm{NaBH}_{4} / \mathrm{CH}_{2} \mathrm{I}_{2}$

6
(R)-1,2-aminoalcohol(10mol\%)

THF, $25^{\circ} \mathrm{C}$<smiles>C[C@@H](O)c1ccccc1</smiles>

7

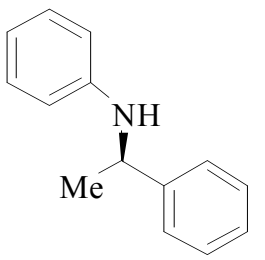

8

\section{Scheme 2.}

ee). In each case the $(S)$-enantiomer of the secondary alcohol (7) was formed preferentially.

The use of $\mathrm{I}_{2}$ in place of $\mathrm{CH}_{2} \mathrm{I}_{2}$ led to a decreased ee and yield. In the absence of additive $\left(\mathrm{CH}_{2} \mathrm{I}_{2}\right.$ and $\left.\mathrm{I}_{2}\right)$, the acetophenone (5) and phenyl (1-phenylethylidene)amine (6) re- mained uninfected. Upon the addition of $\mathrm{CH}_{2} \mathrm{I}_{2}$, evolution of $\mathrm{CH}_{4}$ was noticed, indicating that the formation of $\mathrm{BH}_{3}$. THF in situ from sodium borohydride is essential for the reduction. Chiral aminoalcohol $(R)$-valinol (3) with $10 \mathrm{~mol} \%$ or $100 \mathrm{~mol} \%$ in THF gave maximum selectivity (Table 1).

Table 1. Oxazaborolidine-Mediated Reduction of Acetophenone and Phenyl-(1-Phenylethylidene)Amine ${ }^{\mathrm{a}}$

\begin{tabular}{|c|c|c|c|c|c|}
\hline Substrat & Additive & Catalyst (mol \%) & Yield $(\%)^{b}$ & Configuaration $^{\mathrm{c}}$ & ee $(\%)$ \\
\hline \multirow{7}{*}{ Acetophenone } & $\mathrm{CH}_{2} \mathrm{I}_{2}$ & None & 45 & - & $0^{\mathrm{d}}$ \\
\hline & $\mathrm{CH}_{2} \mathrm{I}_{2}$ & $1(10)$ & 84 & $S$ & $72^{\mathrm{d}}$ \\
\hline & $\mathrm{I}_{2}$ & $\mathbf{1}(10)$ & 73 & $S$ & $68^{\mathrm{d}}$ \\
\hline & $\mathrm{CH}_{2} \mathrm{I}_{2}$ & $2(10)$ & 94 & $S$ & $87^{\mathrm{d}}$ \\
\hline & $\mathrm{I}_{2}$ & $2(10)$ & 85 & $S$ & $76^{\mathrm{d}}$ \\
\hline & $\mathrm{CH}_{2} \mathrm{I}_{2}$ & $3(10)$ & 51 & $S$ & $23^{\mathrm{d}}$ \\
\hline & $\mathrm{CH}_{2} \mathrm{I}_{2}$ & $4(10)$ & 88 & $S$ & $49^{\mathrm{d}}$ \\
\hline \multirow{7}{*}{ Phenyl (1-phenylethylidene)amine } & $\mathrm{CH}_{2} \mathrm{I}_{2}$ & None & 92 & - & $0^{\mathrm{e}}$ \\
\hline & $\mathrm{CH}_{2} \mathrm{I}_{2}$ & $1(100)$ & 65 & $S$ & $70^{\mathrm{e}}$ \\
\hline & $\mathrm{I}_{2}$ & $\mathbf{1}(100)$ & 53 & $S$ & $66^{\mathrm{e}}$ \\
\hline & $\mathrm{CH}_{2} \mathrm{I}_{2}$ & $2(100)$ & 72 & $S$ & $74^{\mathrm{e}}$ \\
\hline & $\mathrm{I}_{2}$ & $2(100)$ & 64 & $S$ & $67^{\mathrm{e}}$ \\
\hline & $\mathrm{CH}_{2} \mathrm{I}_{2}$ & $3(100)$ & 49 & $S$ & $32^{\mathrm{e}}$ \\
\hline & $\mathrm{CH}_{2} \mathrm{I}_{2}$ & $4(100)$ & 58 & $S$ & $64^{\mathrm{e}}$ \\
\hline
\end{tabular}

${ }^{a}$ All reactions were carried out using $4 \mathrm{mmol}_{\text {of }} \mathrm{NaBH}_{4}, 2 \mathrm{mmol}$ of $\mathrm{CH}_{2} \mathrm{I}_{2}, 5 \mathrm{mmol}$ of ketone or imine in $25 \mathrm{~mL}$ of solvent at $25{ }^{\circ} \mathrm{C}$.

${ }^{b}$ Isolated yields of the corresponding secondary alcohol and amine.

${ }^{\mathrm{c}}$ Absolute configurations were assigned by comparison of the sign of the specific rotation with that of a literature value.

${ }^{\mathrm{d}}$ Based on reported maximum $[20][\alpha]^{20}{ }_{\mathrm{D}}=-45,2(c 2, \mathrm{MeOH})$ for $(S)$-isomer.

${ }^{\mathrm{e}}$ Based on reported maximum $[21][\alpha]_{\mathrm{D}}^{24}=+17(c 1, \mathrm{MeOH})$ for $(S)$-isomer. 
The reduction of Ketone (5) with $\mathrm{NaBH}_{4} / \mathrm{CH}_{2} \mathrm{I}_{2}$ in the absence of oxazaborolidines catalysts was sluggish. In contrast the uncatalysed reduction of imine (6) with this reducing agent was essentially complete within $10 \mathrm{~min}$.

To verify the rationale, a coordination between a sulfur atom which is a softer Lewis base in the $(R)$ - methioninol, and borane provides low selectivity and yield. The results support our rationale.

In the reduction of $N$-substituted imine (6) the best enantioselectivety with up to $74 \%$ ee was achieved when $(R)$ valinol (2) with $100 \mathrm{~mol} \%$ was utilized as catalyst whereas, the $(R)$-prolinol (4) gave the amine $(\mathbf{8})$ in $64 \%$ ee $(58 \%$ yield) and with $(R)$-methioninol (3) in $32 \%$ ee ( $49 \%$ yield). We observed that the $\mathrm{NaBH}_{4} / \mathrm{CH}_{2} \mathrm{I}_{2}$ reagent system in the presence of catalyst $(R)$-leucinol (1) (100 mol\%) yielded the desired amine $(\mathbf{8})$ in $70 \%$ ee and $65 \%$ yield, reduction of imine (6) with $\mathrm{NaBH}_{4} / \mathrm{CH}_{2} \mathrm{I}_{2}$ and 1,2 amino alcohol did indeed give rise predominantly to the $(S)$-amine $(\mathbf{8})$.

Based on the rationale, the limited success shown in the reduction of $N$-substituted imine (6) due to the low electrophilicity of the imine carbon and the rapid equilibration between the $E$ an $Z$ isomer [19].

\section{MECHANISTIC CONSIDERATION}

In 1987, Corey et al. [3b] Reported ${ }^{1} \mathrm{H}$ NMR, ${ }^{11}$ BNMR and infrared spectroscopic evidence of the structure of valinol chiral 3. The oxazaborolidine $\mathbf{3}$ is unable to reduce ketones and imines [1a,c-f,3]. The addition of second equivalent of borane at the opposite site of the iso-propyl group gives the effective chiral reducing agent $3^{\prime}$. The complex is sterically unfavorable 3".

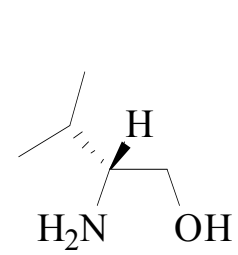

3

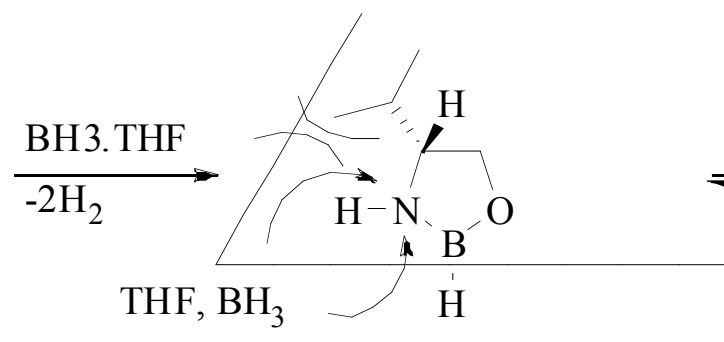

oxazaborolidine 3
Our adaptation of the mechanism for the reduction of ketones and imines to alcohols and amines agrees with high enantioselectivity observed. The nitrogen or oxygen of the the anti-geometric isomer is complexed by the endocyclic borane allowing the chiral hydrogene transfer via a sixmembered cyclic transition state $\mathbf{9}$.

At this stage, the stereogenic centre is formed, benzylic amines or alcohols and $(R)$-Valinol are obtained after workup. This hypothetical mechanism illustrates a general feature of the reaction.

\section{CONCLUSION}

In conclusion, the asymmetric reduction of prochiral ketones and $\mathrm{N}$-substituted imines using $\mathrm{NaBH}_{4} / \mathrm{CH}_{2} \mathrm{I}_{2}$ reagent system gave the corresponding chiral secondary alcohol and amine in moderate to good selectivity. This method offers a relatively simple and inexpensive approach to this widely used transformation in syntheses.

\section{EXPERIMENTAL}

\subsection{General}

IR spectra were determined using a Shimadzu IR-435 spectrometer. ${ }^{1} \mathrm{H}$ NMR and ${ }^{13} \mathrm{C}$ NMR spectra were recorded at 400 and $100 \mathrm{MHz}$ using JNM-A 400 spectrometer respectively. Mass spectra were recorded on a JEOL JMS-SX102A mass spectrometer. Optical rotations were taken with a JASCO p-1010 polarimeter. Tetrahydrofurane (THF) was distilled from sodium benzophenone ketyl before use. TLC was carried out on Merck glass plates precoated with silica gel 60F-254 $(0.25 \mathrm{~mm})$ and column chromatography was performed using Merck 23-400 mesh silica gel. All aminoal-
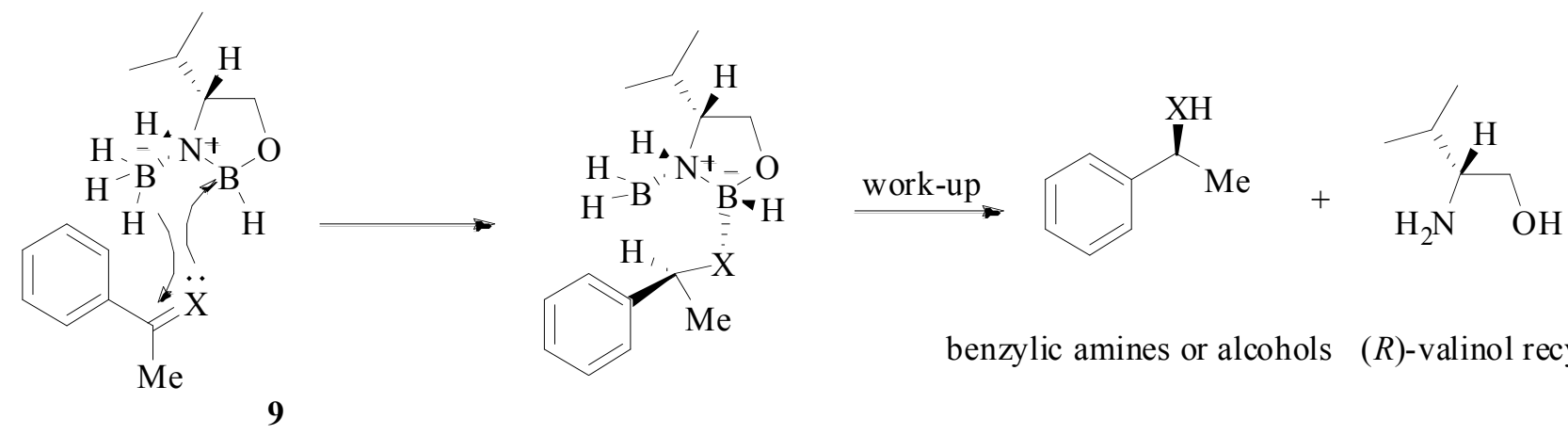

benzylic amines or alcohols $(R)$-valinol recycled

$\mathrm{X}=\mathrm{N}-\mathrm{Ph}$ ou $\mathrm{O}$ 
cohols and sodium borohydride were purchased from the Aldrich Chemical.

\subsection{General Procedure for the Asymmetric Reduction of Acetophenone Utilizing the $\mathrm{NaBH}_{4} / \mathrm{CH}_{2} \mathrm{I}_{2}$ Reagent Sys- tem}

Sodium borohydride $(0.19 \mathrm{~g}, 4 \mathrm{mmol})$ and $(R)$-valinol $(0.052 \mathrm{~g}, 0.5 \mathrm{mmol})$ in THF $(12 \mathrm{~mL})$ were taken in a two neck RB flask. The contents were stirred at $25^{\circ} \mathrm{C}$ for $15 \mathrm{~min}$ under an argon atmosphere. Methylene iodide $(0.54 \mathrm{~g}, 2$ mmol) was added using a syringe and the reaction mixture was stirred for about $30 \mathrm{~min}$. Acetophenone (5) $(0.60 \mathrm{~g}, 5$ $\mathrm{mmol})$ in THF $(12 \mathrm{~mL})$ was added dropwise through a pressure equalizer for about 30 min under an argon atmosphere. The reaction mixture was stirred until the ketone had disappeared. The mixture was carefully quenched with $3 \mathrm{M} \mathrm{HCl}$ $(10 \mathrm{~mL})$. The organic layer was extracted with ether $(3 \times 30$ $\mathrm{mL}$ ). The combined organic extract was washed with brine $(30 \mathrm{~mL})$, dried over anhydrous $\mathrm{Na}_{2} \mathrm{SO}_{4}$, and the solvent was evaporated to give a yellow residue. The residue was purified on a silica gel column chromatography to obtain the $(S)$ 1-phenylethanol (7) using hexane/ethyl acetate (973) as eluent, identified by comparison (GC, ${ }^{1} \mathrm{H}$ NMR) with an authentic sample. Conditions of GC analyses: $\beta$-DEX 120, 120 column, $30 \mathrm{~m}$ length, $0.25 \mathrm{~mm}$ internal diameter, isotherm temperature program, $\mathrm{He}$ as carier gas $(2.4 \mathrm{~mL} / \mathrm{min})$. $t_{\mathrm{R}} R$ isomer $52.1 \mathrm{~min}, t_{\mathrm{R}} S$ isomer $55.7 \mathrm{~min}$.

\subsection{General Procedure for the Asymmetric Reduction of Acetophenone Utilizing the $\mathrm{NaBH}_{4} / \mathrm{I}_{2}$ Reagent System}

Sodium borohydride $(0.19 \mathrm{~g}, 4 \mathrm{mmol})$ and $(R)$-leucinol $(0.059 \mathrm{~g}, 0.5 \mathrm{mmol})$ in THF $(12 \mathrm{~mL})$ were taken in a two neck RB flask. The contents were stirred at $25^{\circ} \mathrm{C}$ for $5 \mathrm{~min}$ under an argon atmosphere. $\mathrm{I}_{2}(0.50 \mathrm{~g}, 2 \mathrm{mmol})$ dissolved in THF (12 mL) was added slowly for about 15-20 min through a pressure equalizer at $0{ }^{\circ} \mathrm{C}$ under an argon atmosphere and the reaction mixture was allowed to stir at $0{ }^{\circ} \mathrm{C}$ for about 30 min. The reaction mixture was then slowly brought to $25^{\circ} \mathrm{C}$ and was stirred for about 10 min under an argon atmosphere. Acetophenone (5) $(0.60 \mathrm{~g}, 5 \mathrm{mmol})$ in THF $(15 \mathrm{~mL})$ was added dropwise through a pressure equalizer for about 30 min. The reaction mixture was stirred until the ketone had disappeared. The mixture was carefully quenched with $3 \mathrm{M}$ $\mathrm{HCl}(10 \mathrm{~mL})$. The organic layer was extracted with ether $(3 \times 30 \mathrm{~mL})$. The combined organic extract was washed with brine $(30 \mathrm{~mL})$, dried over anhydrous $\mathrm{Na}_{2} \mathrm{SO}_{4}$, and the solvent was evaporated to give a yellow residue. The residue was purified on a silica gel column chromatography to obtain the (S)-1-phenylethanol (7) using hexane/ethyl acetate (973) as eluent, identified by comparison (GC, ${ }^{\mathrm{T}} \mathrm{H} \mathrm{NMR}$ ) with an authentic sample. Conditions of GC analyses: $\beta$-DEX 120, 120 column, $30 \mathrm{~m}$ length, $0.25 \mathrm{~mm}$ internal diameter, isotherm temperature program, $\mathrm{He}$ as carier gas $(2.4 \mathrm{~mL} / \mathrm{min})$. $t_{\mathrm{R}} R$ isomer $52.1 \mathrm{~min}, t_{\mathrm{R}} S$ isomer $55.7 \mathrm{~min}$.

\subsection{General Procedure for the Asymmetric Reduction of Phenyl-(1-Phenylethylidene)Amine Utilizing the $\mathrm{NaBH}_{4} / \mathrm{CH}_{2} \mathrm{I}_{2}$ Reagent System}

Sodium borohydride $(0.19 \mathrm{~g}, 4 \mathrm{mmol})$ and $(R)$-valinol $(0.52 \mathrm{~g}, 5 \mathrm{mmol})$ in THF $(12 \mathrm{~mL})$ were taken in a two neck RB flask. The contents were stirred at $25{ }^{\circ} \mathrm{C}$ for $15 \mathrm{~min}$ under an argon atmosphere. Methylene iodide $(0.54 \mathrm{~g}, 2 \mathrm{mmol})$ was added using a syringe and the reaction mixture was stirred for about $30 \mathrm{~min}$. Phenyl-(1-phenylethylidene)amine (6) $(0.98 \mathrm{~g}, 5 \mathrm{mmol})$ in THF $(3 \mathrm{~mL})$ was slowly added at 0 ${ }^{\circ} \mathrm{C}$ under an argon atmosphere. After $2 \mathrm{~h}$, a $3 \mathrm{M}$ sodium hydroxide $(5 \mathrm{~mL})$ was added dropwise, and stirring was continued for $1 \mathrm{~h}$. layers were separated and the aqueous layer was extracted with diethyl ether $(3 \times 5 \mathrm{~mL})$. The extracts were combined and dried with magnesium sulphate. Evaporation of the solvents and flash column chromatography on silica gel (petroleum ether / ethyl acetate, 8:2) afforded (S)-phenyl(1-phenylethyl)amine (8), identified by comparison (GC, ${ }^{1} \mathrm{H}$ NMR) with an authentic sample. Elemental analysis, Calcd C, 85.24; H, 7.66; N, 7.10. Found: C, 85.39; H, 7.7; N, 7.15. for $S$ isomer $[\alpha]^{24}{ }_{D}=+17^{\circ}\left(C 1, \mathrm{CH}_{3} \mathrm{OH}\right)$; lit. $[21][\alpha]^{24}{ }_{578}=$ $+18.5^{\circ}\left(\mathrm{C} 1, \mathrm{CH}_{3} \mathrm{OH}\right)$. for $R$ isomer $[\alpha]^{24}=\sim-16^{\circ}(C 1$,

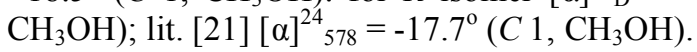

\subsection{General Procedure for the Asymmetric Reduction of Phenyl-(1-Phenylethylidene)Amine Utilizing the $\mathrm{NaBH}_{4} / \mathbf{I}_{2}$ Reagent System}

Sodium borohydride $(0.19 \mathrm{~g}, 4 \mathrm{mmol})$ and $(R)$-leucinol $(0.59 \mathrm{~g}, 5 \mathrm{mmol})$ in THF $(12 \mathrm{~mL})$ were taken in a two neck RB flask. The contents were stirred at $25{ }^{\circ} \mathrm{C}$ for 5 min under an argon atmosphere. $\mathrm{I}_{2}(0.50 \mathrm{~g}, 2 \mathrm{mmol})$ dissolved in THF $(12 \mathrm{~mL})$ was added slowly for about $15-20$ min through a pressure equalizer at $0{ }^{\circ} \mathrm{C}$ under an argon atmosphere and the reaction mixture was allowed to stir at $0{ }^{\circ} \mathrm{C}$ for about $30 \mathrm{~min}$. The reaction mixture was then slowly brought to $25^{\circ} \mathrm{C}$ and was stirred for about 10 min under an argon atmosphere, Phenyl-(1-phenylethylidene)amine (6) $(0.98 \mathrm{~g}, 5 \mathrm{mmol})$ in THF $(3 \mathrm{~mL})$ was slowly added through a pressure equalizer for about $30 \mathrm{~min}$ at $0{ }^{\circ} \mathrm{C}$ under an argon atmosphere. After 2 $\mathrm{h}$, a $3 \mathrm{M}$ sodium hydroxide ( $5 \mathrm{~mL}$ ) was added drop wise, and stirring was continued for $1 \mathrm{~h}$. layers were separated and the aqueous layer was extracted with diethyl ether $(3 \times 5 \mathrm{~mL})$. The extracts were combined and dried with magnesium sulphate. Evaporation of the solvents and flash column chromatography on silica gel (petroleum ether / ethyl acetate, 8:2) afforded $(S)$-phenyl-(1-phenylethyl)amine (8), identified by comparison (GC, ${ }^{1} \mathrm{H}$ NMR) with an authentic sample. Elemental analysis, Calcd C, 85.24; H, 7.66; N, 7.10. Found: C, $85.39 ; \mathrm{H}, 7.7 ; \mathrm{N}, 7.15$. for $S$ isomer $[\alpha]^{24}{ }_{\mathrm{D}}=+17^{\circ}(C$ $\left.1, \mathrm{CH}_{3} \mathrm{OH}\right)$; lit. [21] $[\alpha]^{24}{ }_{578}=+18.5^{\circ}\left(\mathrm{C} 1, \mathrm{CH}_{3} \mathrm{OH}\right)$, for $R$ isomer $[\alpha]^{24}=\sim-16^{\circ}\left(C 1, \mathrm{CH}_{3} \mathrm{OH}\right)$; lit. $[21][\alpha]^{24}{ }_{578}=$ $17.7^{\circ}\left(\mathrm{C} 1, \mathrm{CH}_{3} \mathrm{OH}\right)$.

\section{REFERENCES}

[1] For reviews see: (a) Glushkov, V. A.; Tolstikov, A. G. Russ. Chem Rev., 2004, 73, 581-608; (b) Corey, E. J. Angew. Chem., Int. Ed., 2002, 41, 1650-1667; (c) Fache, F.; Schultz, E.; Tommasino, M.; Lemaire, M. Chem. Rev., 2000, 100, 2159-2231; (d) Corey, E. J.; Helal, C. J. Angew. Chem., Int. Ed., 1998, 37, 1986-2012; (e) Deloux, L.; Srebnik, M. Chem. Rev., 1993, 93, 763-784; (f) Singh, V. K. Synthesis, 1992, 605-617.

[2] For representative examples see: (a) Joshi, N. N.; Srebnik, M.; Brown, H. C. Tetrahedron Lett., 1989, 30, 5551-5554; (b) Ryu, D. H.; Corey, E. J. J. Am. Chem. Soc., 2004, 126, 8106-8107; (c) Takasu, M.; Yamamoto, H. Synlett, 1990, 194-197; (d) Sartor, D.; Saffrich, J.; Helmchen, G. Synlett, 1990, 197-199; (e) Corey, E. J.; Shibata, T.; Lee, T. W. J. Am. Chem. Soc., 2002, 124, 3808-3809; (f) Berkessel, A.; Mukherjee, S.; Lex, J. Synlett, 2006, 41-44; $(g)$ Kinugasa, M.; Harada, T.; Oku, A. Tetrahedron Lett., 1998, 39, 4529-4532; (h) Harada, T.; Egusa, T.; Oku, A. Tetrahedron Lett., 1998, 39, 5535-5536; (i) Bringmann, G.; Hartung, T. Angew. Chem., Int. Ed. Engl., 1992, 31, 761; (j) Kiyooka, S.; Kaneko, Y.; 
Komura, M.; Matsuo, H.; Nakano, M. J. Org. Chem., 1991, 56, 2276-2278.

[3] (a) Itsuno, S.; Nakano, M.; Miyazaki, K.; Masuda, H.; Ito, K. $J$. Chem. Soc., Perkin Trans. 1, 1985, 2039-2044; (b) Corey, E. J.; Bakshi, R. K.; Shibata, S. J. Am. Chem. Soc., 1987, 109, 55515553; (c) Itsuno, S.; Sakurai, Y.; Shimizu, K.; Ito, K. J. Chem. Soc., Perkin Trans. 1, 1990, 1859-1863; (d) Cho, B. T.; Ryu, M. H. Bull. Korean Chem. Soc., 1994, 15, 191; (e) Quallich, G. J.; Keavey, K. N.; Woodall, T. M. Tetrahedron Lett., 1995, 36, 4729-4732; (f) Yadav, J. S.; Reddy, P. T.; Hashim, S. R. Synlett, 2000, 7, 10491051; (g) Fontaine, E.; Namane, C.; Meneyrol, J.; Geslin, M.; Serva, L.; Roussey, E.; Tissandie, S.; Maftouh, M.; Roger, P. Tetrahedron: Asymmetry, 2001, 12, 2185-2189; (h) Krzeminski, M. P.; Zaidlewicz, M. Tetrahedron: Asymmetry, 2003, 14, 1463-1466.

[4] Periasamy, M.; Kanth, J. V. B.; Prasad, A. S. B. Tetrahedron, 1994, 50, 6411-6416.

[5] Brown, H. C. Ed.; Organic Synthesis via Boranes., Wiley - Interscience, New York 1975.

[6] Itsuno, S.; Sakurai, Y.; Shimizu, K.; Ito, K. J. Chem. Soc., Perkin Trans., 1, 1989, 1548.

[7] (a) Degni, S.; Wilén, C-E.; leino, R. Org. Lett., 2001, 16, 25512554; (b) Jiang, B.; Feng, Y.; Zheng, J. Tetrahedron Lett., 2000, $41,10281-10283$

[8] Hu, J-B.; Zhao, G.; Ding, Z. D. Angew. Chem., Int. Ed., 2001, 40, $1109-1111$.

[9] (a) Huttenhain, S. H. Synth. Commun., 2007, 37, 1141-1146; (b) Gensler, W. J.; Johnson, F.; Sloan, A. D. B. J. Am. Chem. Soc., 1960, 82, 6074; (c) Grabbe, P.; Garcia, G. A.; Rius, C. J. Chem. Soc. Perkin Trans. 1, 1973, 810.

[10] (a) McKennon, M. J.; Meyers, A. I.; Drauz, K.; Schwarm, M. J. Org. Chem., 1993, 58, 3568; (b) Prasad, A. S. B.; Kanth, J. V.
B.; Periasamy, M. Tetrahedron, 1992, 48, 4623; (c) Kanth, J. V. B.; Periasamy, M. J. Org. Chem., 1991, 56, 5964; (d) Karimi, B.; Zareyee, D. Synthesis, 2003, 335; (e) Periasamy, M.; Sivakumar, S.; Reddy, M. N. Synthesis, 2003, 1965.

[11] Okawa, H.; Katsuki, T.; Nakamura, M.; Kumagai, N, Shuin, Y.; Shinmyozu, T.; Kida, S. J. Chem. Soc. Chem. Commun., 1989, 139-140.

[12] Cho, B. T.; Kang, S. K.; Kim, M. S.; Ryu, S. R.; An, D. K. Tetrahedron, 2006, 62, 8164-8168.

[13] (a) Kano, S.; Yuasa, Y.; Shibuya, S. J. Chem. Soc. Chem. Commun., 1979, 796; (b) Satoh, T.; Suzuki, S. Tetrahedron Lett., 1969, 4555-4558.

[14] Abiko, A.; Masamune, S. Tetrahedron Lett., 1992, 33, 5517-5518.

[15] Maiti, D. K.; Bhattacharya, P. K. Synth. Commun., 1998, 28, 99108.

[16] Lukyanenko, N. G.; Lobach, A. V.; Leus, O. N. Russ. J. Org. Chem., 2003, 39, 1042-1047.

[17] Chen, W-Y.; Lu, J.; Zhang, Y-W.; Shen, Z-X. Chinese. Chem. Lett., 2002, 13, 931-932.

[18] Nad, M. M.; Kocheshkov. K.A. Russ. Chem. Bull., 1957, 6, 11451146.

[19] (a) For a general review on imine reduction, see Hutchins, R. O.; Hutchins, M. K. In: Trost, R. M., Ed.; Comprehensive Org. Synth., Pergamon: New York, 1991; Vol. 8, pp. 25-78. For asymmetric reductions of imines, see: (b) Zhu, Q.-C.; Hutchins, R. O.; Hutchins, M. K. Org. Prep. Proced. Int., 1994, 26, 193. (c) Kobayashi, S.; Ishitani, H. Chem. Rev., 1999, 99, 1069.

[20] Li, K.; Zhou, Z.; Wang, L.; Chen, Q.; Zhao, G.; Zhou, Q.; Tang, C. Tetrahedron Asymmetry, 2003, 14, 95-100.

[21] Wittig, G.; Thiele, U. Liebigs. Ann. Chem., 1969, 726, 1.

(c) Kettouche and Djerourou; Licensee Bentham Open.

This is an open access article licensed under the terms of the Creative Commons Attribution Non-Commercial License (http://creativecommons.org/licenses/by$\mathrm{nc} / 3.0 /$ ) which permits unrestricted, non-commercial use, distribution and reproduction in any medium, provided the work is properly cited. 